\title{
PELATIHAN PENGOLAHAN BUAH PANDAN TIKAR (Pandanus tectorius Park.) MENJADI TEPUNG DAN COOKIES DI KAMPUNG SIDEY BARU, DISTRIK SIDEY, MANOKWARI
}

\section{Pandan Tikar (Pandanus tectorius Park.) Fruit Processing into Flour and Cookies in Sidey Baru Village, Sidey District, Manokwari}

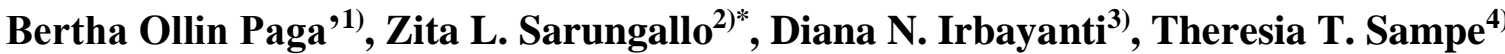 \\ ${ }^{1)}$ Prodi Teknik Pertanian dan Biosistem, Fakultas Teknologi Pertanian, Universitas Papua \\ ${ }^{2}$ Prodi Teknologi Hasil Pertanian, Fakultas Teknologi Pertanian, Universitas Papua \\ ${ }^{3)}$ Prodi Agribisnis, Fakultas Pertanian, Universitas Papua \\ 4)Prodi Biologi, Fakultas Keguruan Ilmu Pendidikan, Universitas Papua
}

Article history

Received: Mar 06, 2021;

Accepted: Aug 17, 2021

* Corresponding author:

E-mail:

zlsarungallo@yahoo.com

DOI: https://doi.org/10.465

49/igkojei.v2i3.243

\begin{abstract}
Sidey Baru is one of the villages in Manokwari Regency, located near the beach where Pandan Tikar (Pandanus tectorius Park.) plant can be found, which has been underutilized. The fruit is nutritious enough to be developed as a food ingredient that can add more value to the product. This community service activity aims to be able to increase the community's ability to process pandan fruit into flour and its derivative products, for the local families to be able to meet their needs, and to market the product to improve the community's economy. This community service activity was carried out in the form of direct training with the people of the village of Sidey Baru, especially women from the PKK organization, business groups, and village officials, with the hope that the community could produce flour and cookies from Pandan Tikar fruits in a sustainable manner so that it could help improve the community's economy. The training on making fruit flour and cookies from pandan mat fruit was very attractive to the people of Kampung Sidey Baru because the raw materials are easy to obtain and could be done with simple technology. Overall, participants were able to take part in the training and material training well, so it is hoped that the knowledge and skills gained from the training can be enjoyed by other people. Efforts to increase the added value of Pandan tikar fruit into various highly competitive products can be realized through continuous guidance and assistance by Sidey village officials together with the Faculty of Agricultural Technology, University of Papua.
\end{abstract}

Keywords: Cookies; Flour; Pandanus tectorius; Sago.

\section{ABSTRAK}

Sidey Baru merupakan salah satu kampung yang terletak di Kabupaten Manokwari, terletak dekat pantai dan ditemui tanaman pandan tikar (Pandanus tectorius Park.). Selama ini, buah pandan tikar terbuang begitu saja dan belum dimanfaatkan oleh masyarakat sekitar. Buah pandan tikar mengandung gizi yang memadai sehingga berpotensi sangat baik untuk dikembangkan sebagai bahan pangan yang dapat meningkatkan nilai tambah produk. Kegiatan pengabdian kepada masyarakat (PKM) ini bertujuan untuk dapat menambah keterampilan masyarakat dalam mengolah buah pandan tikar menjadi tepung dan produk turunannya, untuk dapat memenuhi kebutuhan keluarga dan dapat juga dipasarkan untuk peningkatan ekonomi masyarakat. Kegiatan PKM ini dilakukan dalam bentuk pelatihan langsung dengan masyarakat kampung Sidey Baru, khususnya ibu-ibu organisasi PKK, kelompok usaha, dan aparat desa, dengan harapan masyarakat dapat memproduksi tepung dan cookies dari buah pandan tikar secara 
berkelanjutan sehingga dapat membantu meningkatkan perekonomian masyarakat. Pelatihan pembuatan buah pandan tikar menjadi tepung dan cookies sangat diminati masyarakat Kampung Sidey Baru, karena bahan bakunya mudah diperoleh dan pembuatannya menggunakan teknologi yang sederhana. Secara keseluruhan, peserta dapat mengikuti kegiatan pelatihan dan menyerap materi pelatihan dengan baik, sehingga diharapkan pengetahuan dan keterampilan yang diperoleh selama pelatihan dapat diteruskan kepada masyarakat lainnya. Dalam upaya untuk meningkatkan nilai tambah buah pandan tikar menjadi berbagai produk dengan daya saing yang tinggi dapat terwujud melalui pembinaan dan pendampingan secara terus menerus oleh aparat kampung Sidey bekerjasama dengan Tim dari Fakultas Teknologi Pertanian, Universitas Papua.

Kata kunci: cookies; Pandanus tectorius; Sagu; Tepung.

\section{PENDAHULUAN}

Kampung Sidey Baru, Distrik Sidey terletak di sebelah barat ibukota Kabupaten Manokwari dengan jarak $100 \mathrm{~km}$. Distrik Sidey merupakan salah satu wilayah transmigrasi di Kabupaten Manokwari, penghasil komoditas pertanian tanaman pangan yang sangat potensial untuk dikembangkan seperti padi, pisang, keladi, jagung, serta sayur-sayuran. Namun, hasil pertanian tersebut masih sebatas untuk memenuhi kebutuhan konsumsi masyarakat setempat, serta belum ada sentuhan teknologi untuk meningkatkan nilai tambah produk agar nilai ekonominya meningkat. Selain itu, kampung Sidey terletak dekat pantai yang banyak ditemui tanaman pandan tikar (Pandanus tectorius Park.).

Tanaman pandan tikar termasuk dalam suku Pandanaceae, yang berasal dari kawasan Australia Timur dan Kepulauan Pasifik tumbuh alami di sekitar pantai pasifik Polinesia, Mikronesia, Melanisia dan Australia pada ketinggian hingga 600 mdpl. Tinggi Rata-rata pohon pandan tikar bisa mencapai 10 meter, ketika ukurannya mencapai empat meter, batangnya tumbuh tunggal, setelah itu tumbuh cabang-cabang. Tanaman ini dapat tumbuh baik dengan intensitas cahaya matahari penuh di tanah gambut, tanah berkapur dan tanah pesisir dengan kadar garam tinggi, serta tahan terhadap hembusan angin kencang karena memiliki akar napas atau akar tunggang dan tajuk yang luas dengan daun-daun yang rapat (Forbes dan Broadhead, 2007); seperti yang diperlihatkan pada Gambar 1a. Ditambahkan pula bahwa buahnya berbentuk bulat telur dan berbentuk bola dengan ukuran garis tengah antara 4$20 \mathrm{~cm}$, kulit buah berwarna hijau, kuning cenderung jingga, dan menjadi kuning sampai orange bila masak; daging buah berserat berwarna kuning muda sampai oranye (Thomson dkk., 2006); seperti yang diperlihatkan pada Gambar 1b. 


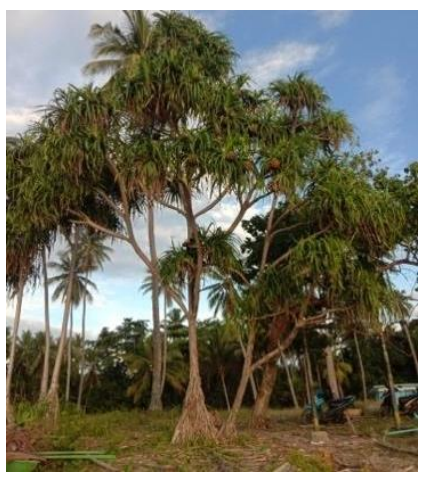

$\mathbf{a}$

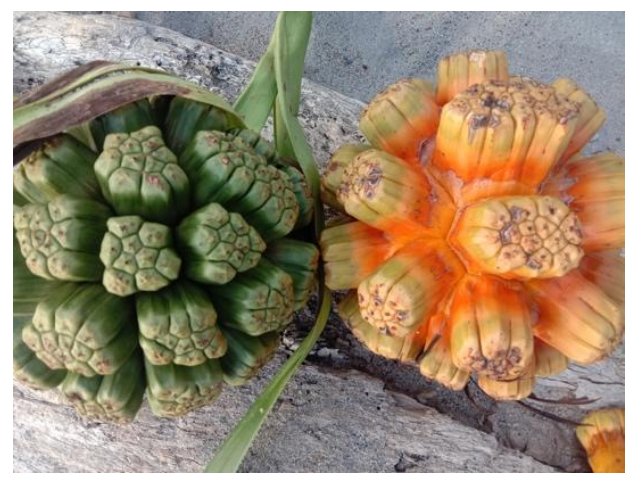

b

Gambar 1. Pohon pandan tikar (a) dan buah Pandan Tikar (b) di Distrik Sidey

Selama ini, buah pandan tikar belum dimanfaatkan oleh masyarakat di sekitar Distrik Sidey, bahkan terbuang begitu saja, karena kurangnya pengetahuan dan ketersediaan teknologi yang terbatas. Sementara itu, berdasarkan kajian yang telah dilakukan oleh tim peneliti di Fakultas Teknologi Pertanian (Fateta), melaporkan bahwa buah pandan tikar memiliki rasa yang manis asam, dengan aroma pandan yang wangi, berwarna kuning pucat sampai oranye, serta mengandung gizi yang meliputi protein, lemak, abu, dan karbohidrat, serta mengandung kalsium, dan $\beta$-karoten, serta kaya vitamin C (Sarungallo dkk., 2018; Maker dkk., 2018). Dengan demikian buah pandan tikar sangat berpotensi untuk dikembangkan sebagai bahan pangan yang dapat meningkatkan nilai tambah produk dan menguntungkan. Disamping itu melalui teknologi pengolahan pangan, harapan kedepannya melalui penganekaragaman olahan tanaman lokal seperti buah pandan tikar ini dapat meningkatkan perekonomian masyarakat di Sidey.

Seperti komoditi buah yang lain, buah pandan tikar tergolong buah yang mudah rusak, sehingga alternatif pemanfaatannya dibuat menjadi tepung, yang dan dapat dimanfaatkan sebagai bahan tambahan dalam berbagai produk pangan seperti cookies. Cookies sagu telah lama dikembangkan namun kurang berkembang karena cita rasa dan nilai gizinya yang dianggap rendah. Oleh karena itu, penggunaan tepung dalam pembuatan cookies dapat meningkatkan cita-rasa dan nilai gizinya (Menanti dkk., 2021). Oleh karena itu untuk meningkatkan pengetahuan masyarakat Sidey dilakukan pelatihan sekaligus sebagai sosialisasi pengolahan buah pandan tikar ini.

Tujuan Kegiatan Pelatihan Pengolahan ini adalah 1). Promosi diversifikasi pangan berbasis sumberdaya lokal sebagai sumber karbohidrat dengan berbagai bentuk olahannya; dan 2) Membangun kesadaran masyarakat untuk kembali pada pola konsumsi pangan lokal melalui penyediaan bahan pangan pokok selain beras. Sasaran kegiatan ini adalah seluruh masyarakat Kampung Sidey Baru, yang terdiri dari kelompok usaha maupun perorangan yang bergerak di bidang pengolahan pangan pada skala rumah tangga. Melalui kegiatan ini diharapkan terbentuk jejaring produksi efisien sehingga mendorong meningkatnya penyediaan pangan lokal di 
masyarakat. Peningkatan kesadaran masyarakat untuk mengkonsumsi pangan lokal dapat diupayakan melalui gerakan atau kampanye diversifikasi pangan dengan menggunakan berbagai media dan kegiatan yang masif dan efektif.

\section{METODE}

\section{WAKTU, TEMPAT DAN PESERTA}

Kegiatan Pelatihan Pengolahan Diversifikasi Produk dari buah pandan tikar dilaksanakan melalui tatap muka dengan para peserta di Aula Kampung Sidey Baru, Distrik Sidey, Kabupaten Manokwari, Provinsi Papua Barat. Pelaksanaan pelatihan dilakukan pada hari Sabtu tanggal 10 April 2021, yang berlangsung dari pukul 13.00 WIT s.d 17.30.00 WIT. Peserta pelatihan ini diikuti oleh 33 orang, yang merupakan perwakilan dari organisasi wanita (PKK), kelompok usaha, dan aparat desa dari Kampung Sidey Baru, Distrik Sidey, Kabupaten Manokwari, Provinsi Papua Barat.

\section{PELAKSANAAN KEGIATAN}

Pelaksanaan kegiatan pengabdian kepada masyarakat (PKM) di daerah Sidey dalam bentuk Pelatihan Pengolahan Diversifikasi Produk dari buah pandan tikar dilakukan dengan 2 tahapan yaitu:

\section{Ceramah dan diskusi.}

Pada tahapan ini, tim penulis memberikan penjelasan terkait sifat-sifat buah pandan tikar dan proses pembuatan tepung serta cookies yang dilakukan secara lisan. Para peserta pelatihan, dibekali dengan ringkasan materi pelatihan guna lebih mengefektifkan dalam memahami penjelasan secara lisan. Selanjutnya diskusi dilakukan untuk mengetahui tingkat pemahaman peserta terhadap materi yang telah diberikan.

\section{Praktek.}

Sebagai tindak lanjut penyajian materi secara lisan, kegiatan praktek dilakukan sehingga peserta pelatihan dapat secara langsung mempraktekkan dan membuktikan materi pelatihan yang telah diberikan. Hal mana membantu peserta untuk memahami dan mampu menerapkan apa yang sudah diperoleh dalam kegiatan penanganan pascapanen buah pandan tikar dan proses pengolahannya menjadi tepung dan cookies. Selama kegiatan praktek berlangsung diskusi dengan peserta terus berlanjut sambil melakukan tahap demi tahap proses pembuatan produk dari buah pandan tikar.

\section{Proses Pembuatan TePUNG DAN COOKIES}

Metode pembuatan tepung buah pandan tikar yang dilaksanakan dalam kegiatan PKM ini, mengacu pada Paiki dkk., (2019) yang telah dimodifikasi. Tahapan pembuatan tepung buah pandan tikar diawali dengan pelepasan phalange dari buah utuh, kemudian disortasi dan dicuci menggunakan air mengalir. Setelah itu, pada bagian buah yang dapat dimakan yaitu bagian yang berwarna kuning 
diiris lebih kurang $2 \mathrm{~mm}$, dan diblansing yaitu dengan cara pengukusan (pada suhu $80-90{ }^{\circ} \mathrm{C}$ ) selama 3 menit kemudian ditiriskan. Blansing merupakan pemanasan pendahuluan di bawah suhu $100{ }^{\circ} \mathrm{C}$ selama beberapa menit, menggunakan air panas dan atau uap panas (Winarno, 2008). Permasalahan utama dalam pembuatan tepung buah pandan tikar adalah terjadinya reaksi pencoklatan enzimatis pada irisan buah oleh senyawa polifenolase yang dapat bereaksi dengan oksigen selama proses pengirisan dan pengeringan. Oleh karena itu, proses blansing dimaksud untuk menginaktifkan enzim fenolase sehingga mencegah terjadinya pencoklatan enzimatis pada irisan buah pandan tikar selama proses pengeringan (Winarno, 2008; Paiki dkk., 2018). Tahap selanjutnya, dilakukan pengeringan irisan buah pandan tikar menggunakan oven (suhu $60{ }^{\circ} \mathrm{C}$ ) selama $\pm 3-5$ jam atau dijemur menggunakan sinar matahari selama 2-3 hari. Pengeringan dihentikan jika irisan yang dikeringkan mudah dipatah. Setelah kering, irisan dihaluskan menggunakan blender kering dan diayak menggunakan ayakan 100 mesh dan dikemas.

Pembuatan cookies dari tepung buah pandan tikar didasarkan pada laporan Menanti dkk., (2021). Pembuatan cookies diawali dengan pembuatan krim, pembentukan adonan, pencetakan, pemanggangan, pendinginan dan pengemasan. Pada tahapan pembuatan krim, mentega dibuat krim terlebih dahulu bersama gula, telur, dan susu skim dikocok menggunakan mixer sampai tercampur merata. Selanjutnya, krim dicampur hingga homogen dengan tepung buah pandan tikar, dan terakhir ditambahkan sagu kering sampai adonan tersebut tidak lengket, selanjutnya adonan dicetak dan dipanggang. Suhu pemanggangan yang umum digunakan yaitu $170^{\circ} \mathrm{C}$ selama $15-20$ menit. Setelah matang cookies didinginkan dan dikemas.

\section{HASIL DAN PEMBAHASAN}

Penyajian materi disampaikan secara menyeluruh kepada semua peserta. Sedangkan pelaksanaan praktek dilakukan dalam bentuk kelompok yang terdiri dari 5-6 orang, sehingga semua peserta memiliki kesempatan berperan aktif dalam membuat produk dari bahan buah pandan tikar. Banyaknya kelompok yang dibuat disesuaikan dengan jumlah produk olahan yang akan dibuat. Adapun produk olahan yang dibuat adalah sirup, selai, tepung dan cookies dari buah pandan tikar. Selanjutnya masing-masing kelompok menyiapkan alat dan bahan yang akan digunakan. Setelah mendapatkan penjelasan dan berdiskusi dengan tim Pelatih, masing-masing kelompok melakukan langkah-langkah pembuatan masing-masing produknya sesuai dengan prosedur pada materi yang telah dibagikan.

Kegitan diawali dengan pembuatan tepung dari buah pandan tikar. Tepung buah pandan tikar yang dihasilkan selanjutnya diolah sebagai bahan dalam pembuatan cookies. 


\section{TEPUNG BUAH PANDAN TIKAR}

Bahan baku yang digunakan dalam pembuatan tepung adalah buah pandan tikar yang agak matang, yaitu buah dengan kandungan karbohidratnya masih tinggi. Buah yang sudah matang dan lewat matang lebih cocok untuk diolah menjadi sirup dan selai, karena kandungan gulanya tinggi (Sarungallo dkk., 2018).

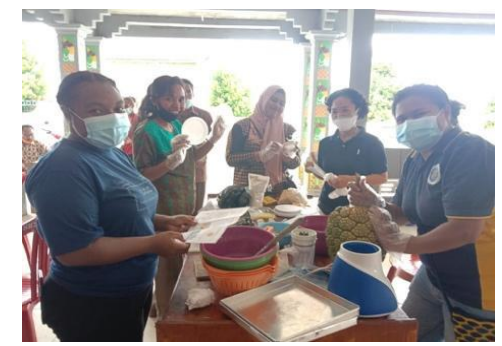

a

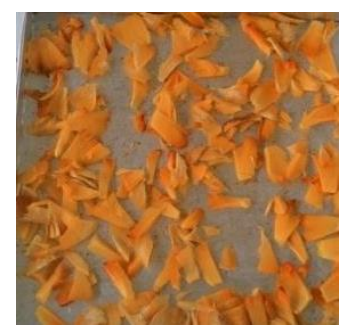

d

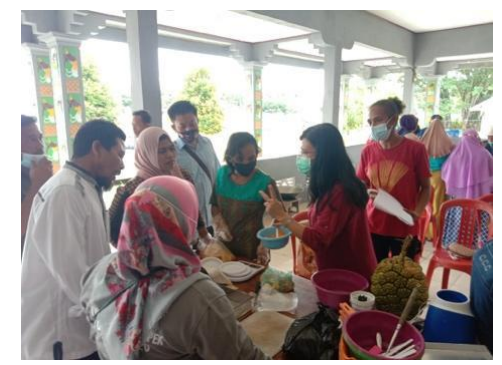

b

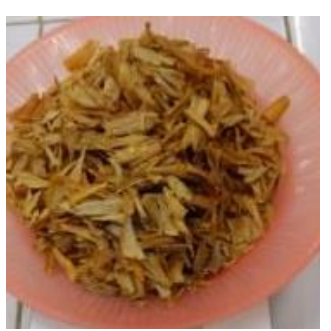

$\mathbf{e}$
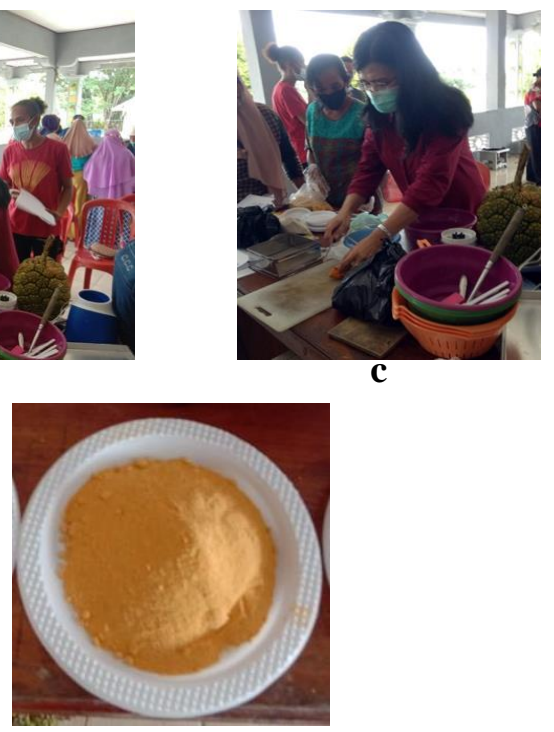

$\mathbf{f}$

Gambar 2. Pelaksanaan praktek pembuatan tepung buah pandan tikar. Persiapan alat dan bahan dalam pembuatan tepung (a); penjelasan proses pembuatan tepung, manfaat dan produk olahannya (b); proses pembuatan tepung diawali dengan pengirisan bagian buah yang dapat dimakan (c); irisan buah pandan tikar (d); irisan kering buah pandan tikar (e); dan tepung buah pandan tikar (f).

Pada pelatihan ini, pertama-tama para peserta menyiapkan alat dan bahan yang akan digunakan. Alat yang digunakan antara lain pisau, baskom, panci kukus, pengaduk, kompor, oven, blender dan talang serta bahannya adalah Phalange atau bulir buah Pandan Tikar sekitar 30-60 bulir perbuah. Setelah alat dan bahan telah siap, mereka mulai membuat tepung pandan tikar dengan langkahlangkah sebagai berikut:

- Pencucian buah pandan tikar matang kemudian melepaskan bulir-bulirnya (phalange), yang dilanjutkan dengan penyortiran.

- Pengirisan bagian buah (phalange) yang dapat dimakan, yaitu pada bagian yang berwarna kuning.

- Proses blansing yaitu dengan cara mengukus hasil irisan pada suhu $80-90^{\circ} \mathrm{C}$ selama 3 menit lalu meniriskannya

- Pengeringan irisan buah pandan tikar yang telah diblansing dengan menggunakan oven pada suhu $60^{\circ} \mathrm{C}$ selama $\pm 3-5$ jam atau hingga irisan bulir buah pandan tersebut mudah dipatahkan.

- Penghancuran dan penghalusan irisan buah kering dengan menggunakan blender, dan diayak menggunakan ayakan 100 mesh. 
- Hasil ayakan tersebut yang diambil sebagai tepung buah pandan tikar yang siap digunakan dalam pengolahan bahan tambahan makan seperti cookies, kue bolu dan sebagainya.

Tepung buah pandan tikar yang dihasilkan berwarna kuning dengan aroma khas pandan (Gambar 2a), sehingga dapat juga digunakan sebagai pewarna dan penambah aroma untuk berbagai jenis produk pangan.

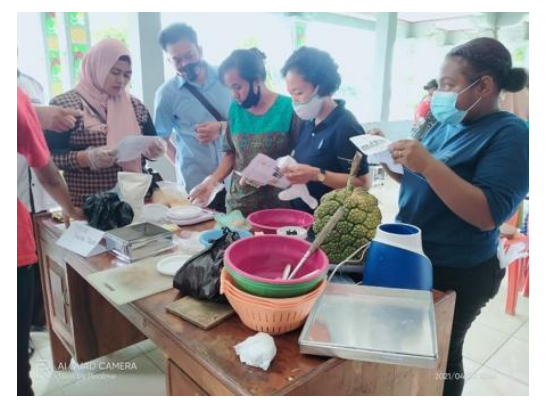

$\mathbf{a}$

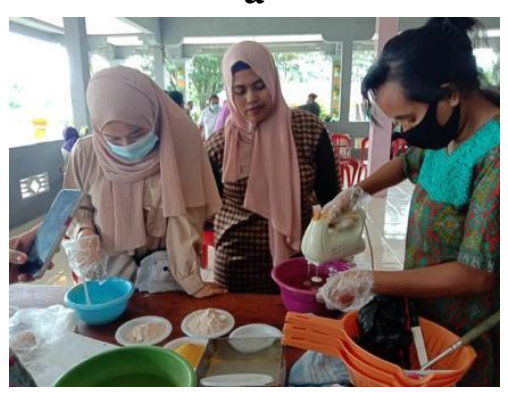

c

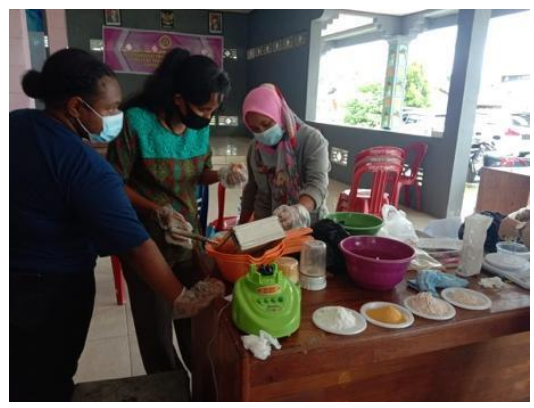

b

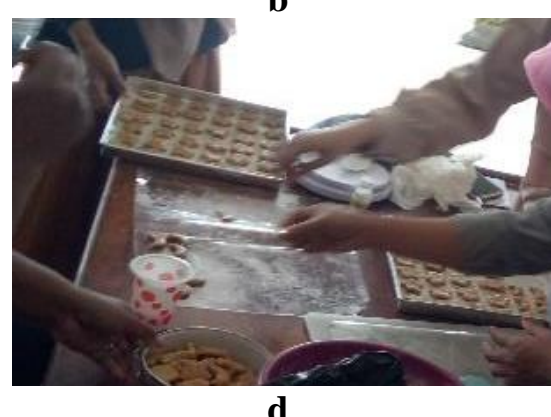

d

Gambar 3. Pelaksanaan praktek pembuatan cookies sagu-pandan tikar. Persiapan alat dan bahan dalam pembuatan cookies (a); proses pembuatan tepung diawali dengan penimbangan bahan-bahan cookies (b); Pencampuran bahan-bahan cookies menggunakan mikser (c); pencetakan cookies sagupandan tikar (d).

\section{COOKIES SAGU - BUAH PANDAN TIKAR}

Cookies sagu pandan tikar merupakan produk turunan dari tepung pandan tikar. Pembuatan cookies dilakukan dengan menambahkan tepung pandan tikar yang telah dibuat. Adapun bahan-bahan yang digunakan pada pembuatan cookies ini adalah:

- 200 g tepung sagu

- $40 \mathrm{~g}$ tepung pandan tikar

- 100 g gula halus

- $120 \mathrm{~g}$ mentega/margarin

- 2 buah kuning telur

- 40 g susu bubuk

- 1 sdt vanili

Bahan-bahan tersebut kemudian diolah dengan langkah-langkah sebagai berikut: 
- Pencampuran mentega, gula halus dan kuning telur dengan menggunakan mixer hingga mengembang dan berwarna pucat

- Penambahan susu bubuk, tepung buah pandan tikar dan pati sagu yang sudah diayak

- Pengadukan dan pencampuran semua bahan tersebut dengan menggunakan spatula sampai adonan kalis.

- Pencetakan adonan cookies membentuknya menyerupai bulatan-bulatan, kemudian dipipihkan dengan garpu sebagai pengganti alat cetak kue.

- Penataan cookies pada loyang pembakaran.

- Pemanggangan adonan cookies yang telah dicetak/bentuk pada oven dengan suhu $170^{\circ} \mathrm{C}$ sampai matang dengan api sedang.

- Pengeluaran cookies dari oven lalu dilakukan pendinginan dan pengaturan dalam toples kemasan.

Hasil olahan cookies sagu yang ditambahkan dengan tepung buah pandan tikar menghasilkan produk dengan warna kuning muda dengan citarasa khas sagu dengan aroma pandan, seperti yang disajikan pada Gambar 4.

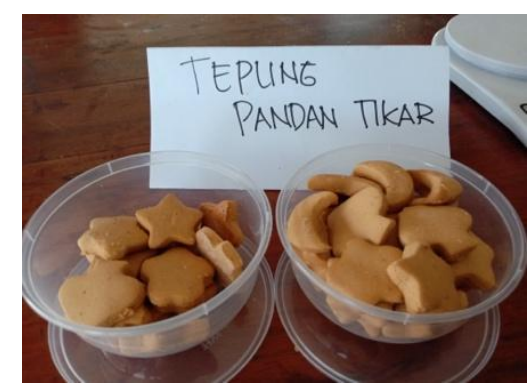

Gambar 4. Produk cookies sagu-pandan tikar

Berdasarkan produk yang dihasilkan dan keaktifan para peserta yang mengikuti pelatihan dengan sangat antusias. Antusiasme peserta ditandai dengan banyaknya pertanyaan yang diajukan baik selama penjelasan materi dan diskusi, serta terlibat aktif dalam praktek pengolahan buah pandan tikar (Gambar 2 dan Gambar 3). Selama ini buah pandan tikar yang banyak tumbuh di sekitar pantai Sidey dibiarkan terbuang begitu saja, karena ketidaktahuan masyarakat bahwa buah tersebut dapat dikonsumsi. Dalam pelatihan ini dijelaskan bahwa kandungan gizi tepung buah pandan tikar dalam berat kering antara lain kadar abu 10,00 \%, protein 5,73\%, lemak 2,24 \%, karbohidrat 82,03\%, serat kasar 24,42 \%, dan total gula 26,00 \% (Paiki dkk., 2018), sehingga dapat berkontribusi dalam meningkatkan mutu dan gizi kue cookies sagu.

Dengan adanya pelatihan ini, pengetahuan dan keterampilan para peserta yang mengikuti pelatihan bertambah. Besar harapan kami, para peserta dapat mentransfer pengetahuannya kepada masyarakat Kampung Sidey Baru sehingga dapat memberikan nilai tambah pada buah pandan tikar, yang selama ini belum dimanfaatkan. 
Kendala dalam kegiatan PKM yang dilakukan adalah jarak Kampung Sidey dengan Kampus Fateta Unipa cukup jauh, sehingga membutuhkan waktu, tenaga dan dana. Namun diharapkan adanya Kerjasama antara kepala kampung dengan Fateta dalam pelaksanaan PKM agar dapat dilakukan secara berkala sehingga pembinaan bagi masyarakat terutama dalam penerapan teknologi hasil pertanian dapat meningkatkan kesejahteraan masyarakat.

\section{KESIMPULAN}

Pelatihan ini menghasilkan produk olahan dari buah pandan tikar yaitu tepung buah dan cookies sagu-buah pandan tikar, yang sangat diminati masyarakat Kampung Sidey Baru, karena bahan bakunya mudah diperoleh dan pembuatannya menggunakan teknologi sederhana. Secara keseluruhan, peserta dapat mengikuti kegiatan pelatihan dan menyerap materi pelatihan dengan baik, sehingga diharapkan pengetahuan dan keterampilan yang diperoleh selama pelatihan dapat diteruskan kepada masyarakat lainnya. Dalam upaya untuk meningkatkan nilai tambah buah pandan tikar menjadi berbagai produk dengan daya saing yang tinggi dapat terwujud melalui pembinaan dan pendampingan secara terus menerus oleh aparat kampung Sidey bekerjasama dengan Tim dari Fakultas Teknologi Pertanian, Universitas Papua.

\section{UCAPAN TERIMA KASIH}

Tim penulis menyampaikan terima kasih dan penghargaan kepada Kepala Kampung Sidey Baru beserta Aparat Desa, serta kepada Fakultas Teknologi Pertanian, Universitas Papua yang telah mendanai pelaksanaan kegiatan PKM ini melalui anggaran PNBP tahun anggaran 2021.

\section{DAFTAR PUSTAKA}

Forbes, K. dan Broadhead, J. 2007. The Role of The Mitigation of Tsunami Impacts. Food and Agriculture Organization of the United Nations, Bangkok.

Maker, D., Sarungallo, Z. L., Santoso, B., Latumahina, R.M.M., Susanti, C, M, E., Sinaga, N. I., Irbayanti D N. 2018. Sifat fisik, kandungan vitamin c dan total padatan buah pandan tikar (Pandanus tectorius Park.) pada tiga tingkat kematangan. Jurnal Agritechnology 1(1): 1-11. https:/doi.org/10.51310/agritechnology.v1i1.5.

Menanti, N.W., Sarungallo, Z.L., Santoso, B. 2021 Karakteristik Fisikokimia Tepung Pandan Tikar (Pandanus tectorius Park.). Pro Food (Jurnal Ilmu dan Teknologi Pangan) 7(1): 831-893.

Paiki, S. N. P., Irman., Sarungallo, Z.L., Latumahina R. M. M., Susanti, C. M. E., Sinaga, N. I., Irbayanti, D. N. 2018. Pengaruh blansing dan perendaman asam sitrat terhadap mutu fisik dan kandungan gizi tepung buah pandan tikar (Pandanus tectorius Park.). Jurnal Agritecnology, 1(2): 76-83. https://doi.org/10.51310/agritechnology.v1i2.20

Sarungallo, Z.L., Susanti, C. M. E., Sinaga, N. I., Irbayanti, D. N. Latumahina R. M. M. 2018. Kandungan Gizi Buah Pandan Laut (Pandanus tectorius Park.) pada Tiga Tingkat Kematangan. Jurnal Aplikasi Teknologi Pangan (JATP), 7(1): 21-26. DOI: 10.17728/jatp. 2577

Thomson, L.A.J., Engelberger, L., Guarino, L., Thaman, R.R., Elevitch, C. 2006. Pandanus tectorius, Permanent Agriculture Resources (PAR). Hōlualoa-Hawai.

Winarno, F.G. 2008. Kimia Pangan dan Gizi. PT Gramedia Pustaka, Jakarta. 